\title{
PENGARUH KOMPETENSI DAN KOMITMEN ORGANISASI TERHADAP KINERJA PEGAWAI PADA KANTOR WILAYAH KEMENTERIAN AGAMA, PROVINSI LAMPUNG
}

\section{THE EFFECT OF COMPETENCES AND ORGANIZATION COMMITMEN TOWARD EMPLOYEES PERFORMANCE AT KANTOR WILAYAH KEMENTERIAN AGAMA PROVINSI LAMPUNG}

\author{
Hasrun Afandi UmpuSinga \\ Dosen Fakultas Ekonomi dan Bisnis IAIN Metro
}

Jl. Ki Hajar Dewantara 15A Kampus, Kota Metro, Lampung, Indonesia, 34112

Email : hasrunafandi@metrouniv.ac.id

Appin Purisky Redaputri

Dosen Fakultas Ekonomi dan Bisnis Universitas Bandar Lampung Jl. Zainal Abidin Pagar Alam No.26, Labuhan Ratu, Kedaton, Bandar

Lampung, Indonesia, 35142

email: appin@ubl.ac.id

Vonny Tiara Narundana

Dosen Fakultas Ekonomi dan Bisnis Universitas Bandar Lampung

Jl. Zainal Abidin Pagar Alam No.26, Labuhan Ratu, Kedaton, Bandar

Lampung, Indonesia, 35142

email: vonny.tiara@ubl.ac.id

\begin{abstract}
This research aims to know the effect of competence and organization commitmen toward employees performance at Kantor Wilayah Kementerian Agama Provinsi Lampung. The type of research used in this research is a descriptive quantitative. This research uses 37 respondents. There are three variables in this study are: two (2) independent variable $\left(X_{1}\right.$ and $\left.X_{2}\right)$ and $1\left(\right.$ one) where the dependent variable competence $\left(X_{1}\right)$ and organization commitmen $\left(X_{2}\right)$ as the independent variable and the performance of employees $(Y)$ as the dependent variable. Based on the results of data processing found the answer hypothesis as follows; there are significant Competence $\left(X_{1}\right)$ toward employees performance $(Y)$, with the level of influence of $69,7 \%$,. There is the effect of organization commitmen $\left(X_{2}\right)$ toward employees performance $(Y)$, with a 47,4\%. There is the influence of competence $\left(X_{1}\right)$ and organization commitmen $\left(X_{2}\right)$ together toward employees performance $(Y)$, with the degree of influence of $72,5 \%$.
\end{abstract}

Keywords: Competence, organization commitmen, employees performance

\begin{abstract}
ABSTRAK
Penelitian ini bertujuan untuk mengetahui pengaruh kompetensi dan komitmen organisasi terhadap kinerja pegawai pada Kantor Wilayah Kementerian Agama Provinsi Lampung.
\end{abstract}


Adapun jenis penelitian yang digunakan dalam penelitian ini adalah deskriptif kuantitatif. Penelitian ini menggunakan 37 responden penelitian. Ada tiga variabel dalam penelitian ini yaitu: 2 (dua) Variabel bebas $\left(\mathrm{X}_{1}\right.$ dan $\left.\mathrm{X}_{2}\right)$ dan 1 (satu) variabel terikat dimana kompetensi $\left(\mathrm{X}_{1}\right)$ dan komitmen organisasi $\left(\mathrm{X}_{2}\right)$ sebagai variabel bebas dan kinerja pegawai (Y) sebagai variabel terikat. Berdasarkan hasil pengolahan data ditemukan jawaban hipotesis yakni sebagai berikut; terdapat pengaruh kompetensi $\left(\mathrm{X}_{1}\right)$ terhadap kinerja pegawai (Y), dengan sebesar $69,7 \%$. Terdapat pengaruh komitmen organisasi $\left(\mathrm{X}_{2}\right)$ terhadap kinerja pegawai $(\mathrm{Y})$ sebesar $47,4 \%$. Terdapat pengaruh kompetensi $\left(\mathrm{X}_{1}\right)$ dan komitmen organisasi $\left(\mathrm{X}_{2}\right)$ secara bersama-sama terhadap kinerja pegawai (Y) sebesar $72,5 \%$.

\section{Kata kunci: Kompetensi, motivasi kerja, kinerja pegawai}

\section{PENDAHULUAN}

Peran sumber daya manusia dalam suatu organisasi merupakan penentu yang sangat penting bagi keefektifan dan keberhasilan organisasi dalam mencapai tujuannya. Keberhasilan dan kinerja seseorang dalam suatu bidang pekerjaan banyak ditentukan oleh tingkat kompetensi, profesionalisme dan juga komitmennya terhadap bidang yang ditekuninya. Sebagai suatu yang berhubungan positif dengan kinerja komitmen yang merupakan suatu sikap dan perilaku yang dapat dipandang sebagai penggerak seseorang dalam bekerja adalah saling terkait erat. Adanya suatu komitmen dapat menjadi suatu dorongan bagi seseorang untuk bekerja lebih baik atau malah sebaliknya menyebabkan seseorang justru meninggalkan pekerjaannya, akibat suatu tuntutan komitmen yang lainnya.

Pentingnya keberadaan sumber daya manusia dalam organisasi berawal dari semakin diperlukannya fungsi sumber daya manusia untuk pelaksanaan dan pengembangan organisasi. Fungsi sumber daya manusia tersebut berawal dari fungsi administrasi sampai fungsi manajemen dan fungsi strategis. Sejalan dengan meningkatnya tuntutan organisasi, maka semakin besar tanggung jawab yang harus diemban oleh pimpinan dalam mengelola dan mengembangkan pegawai karena pegawai harus mampu melaksanakan tugas- tugas dan tanggung jawab sesuai dengan tuntutan organisasi tersebut.

Sumber daya manusia yang berbasis kompetensi dapat meningkatkan kapasitas dan membangun pondasi karena apabila orang - orang yang bekerja dalam organisasi memiliki kompetensi yang tepat sesuai dengan tuntutan pekerjaannya, maka dia akan mampu baik dari segi pengetahuan, keterampilan maupun mental serta karakter produktifnya. Dengan kepemilikan nilai (value) yang kuat, mereka akan selalu siap menghadapi perubahan sesuai dengan tuntutan organisasi tanpa menghilangkan jati dirinya.

Berdasarkan uraian di atas jelaslah bahwa kompetensi merupakan faktor penting dalam meningkatkan kinerja pegawai pada suatu organisasi. Kondisi kompetensi kerja pegawai yang ada di Kantor Wilayah Kementerian Agama Provinsi Lampung masih rendah terlihat dari masih ada pegawai yang bekerja tidak berdasarkan latar belakang pendidikannya sehingga ia tidak menguasai pekerjaannya.

Selain faktor kompetensi komitmen organisasi juga merupakan salah satu faktor yang dapat mempengaruhi kinerja pegawai. Jika kita ingin memahami komitmen organisasi maka kita harus 


\section{Pengaruh Kompetensi... (Hasrun A U - Appin P R - Vonny T N )}

terlebih dahulu melihat dan mengkaji makna dari sikap. "Sikap merupakan pernyataan evaluatif baik yang menyenangkan maupun tidak menyenangkan terhadap objek, individu, atau peristiwa. Hal ini mencerminkan bagaimana perasaan seseorang terhadap sesuatu." (Robbins dan Judge, 2008: 92). Mengapa perlu sikap, jika beranjak dari argumen terakhir menurut Robbins dan Judge bahwa sikap mencerminkan perasaan seseorang terhadap sesuatu maka ketika itulah kita akan dapat melihat bagaimana komitmen organisasi itu terbentuk.

Sikap memiliki tiga komponen utama yaitu komponen kognitif yang dalam hal ini adalah kesadaran atau keyakinan dari sikap, komponen afektif atau perasaan dari sikap dan komponen perilaku yang merupakan niat untuk berperilaku dalam cara tertentu terhadap seseorang atau sesuatu. "Para peneliti telah berasumsi bahwa sikap mempunyai tiga komponen, yaitu kesadaran, perasaan, dan perilaku." (Robbins dan Judge, 2008: 93). Perilaku dari pegawai menjadi sangat penting untuk mengelola sumber daya manusia agar bekerja secara efektif dan maksimal. "To work with people effectively, we have to understand human behavior" Snell dan Bohlander (2007: 4).

Sikap dari seseorang sangatlah banyak, sehingga batasan yang diadakan disini berada pada sikap kerja yang bermakna yang oleh Robbins dan Judge (2008: 93), dalam bukunya yang berjudul Perilaku dan Manajemen Organisasi mengutarakan pernyataan "Sikap kerja berisi evaluasi positif atau negatif yang dimiliki oleh pegawai tentang aspekaspek lingkungan kerja mereka. Sebagian besar penelitian dalam perilaku organisasi berhubungan dengan tiga sikap kepuasan kerja, keterlibatan pekerjaan, dan komitmen organisasi". (Robbins dan Judge, 2008: 99). Kini sudah bisa ditarik benang merah bahwa komitmen organisasi muncul sebagai akibat dari sikap kerja dari seseorang. Robbins dan Judge (2008: 100- 101), memberikan definisi bahwa komitmen organisasi adalah suatu keadaan di mana seorang pegawai memihak organisasi tertentu serta tujuan-tujuan dan keinginannya untuk mempertahankan keanggotaan dalam organisasi tersebut.

Kondisi yang ada pada Kantor Wilayah Kementerian Agama Provinsi Lampung adalah kompetensi pegawai masih rendah terlihat dari masih adanya pegawai yang bekerja tidak berdasarkan latar belakang pendidikannya dan kurangnya pengetahuan tentang pekerjaannya sehingga masih ada pegawai yang tidak menguasai pekerjaannya. Komitmen organisasi masih rendah terlihat dari Kinerja pegawai menurun terlihat dari masih ada pegawai yang lambat dalam penyelesaian suatu pekerjaan dan bahkan cenderung menunda - nunda pekerjaan. Berbagai kendala tersebut mengakibatkan kinerja pegawai menurun yang disebabkan karena motivasi pegawai yang rendah dalam mengerjakan pekerjaan dan didukung dengan komitmen organisasi yang kurang nyaman sehingga pekerjaan pegawai tidak dapat terselesaikan sesuai dengan yang direncanakan akibatnya kinerja pegawai menjadi rendah. Rendahnya kinerja ini terlihat dari lambatnya pegawai dalam menyelesaikan suatu pekerjaan.

Di samping itu tingkat kehadiran pegawai pada Kantor Wilayah Kementerian Agama Provinsi Lampung juga tergolong rendah. Hal ini dapat dilihat pada berikut ini :

Tabel 1. Persentase Kehadiran Pegawai Kantor Wilayah Kementerian Agama Provinsi Lampung

\begin{tabular}{ccc}
\hline Bulan & $\begin{array}{c}\text { Kehadiran } \\
\text { Pegawai (\%) }\end{array}$ & Target \\
\hline Januari & $75 \%$ & $100 \%$ \\
Februari & $70 \%$ & $100 \%$ \\
Maret & $80 \%$ & $100 \%$ \\
April & $80 \%$ & $100 \%$ \\
\hline
\end{tabular}


Jurnal Manajemen dan Bisnis Vol. 11 No. 1 Oktober 2020: 35 - 52

\begin{tabular}{ccc}
\hline Mei & $75 \%$ & $100 \%$ \\
Juni & $80 \%$ & $100 \%$ \\
Juli & $80 \%$ & $100 \%$ \\
Agustus & $70 \%$ & $100 \%$ \\
September & $75 \%$ & $100 \%$ \\
Oktober & $85 \%$ & $100 \%$ \\
November & $80 \%$ & $100 \%$ \\
Desember & $80 \%$ & $100 \%$ \\
\hline Jumlah & $\mathbf{7 7 , 5 \%}$ & $\mathbf{1 0 0 \%}$ \\
Rata - Rata & \\
\hline Sumber: Subbag Kepegawaian Kantor \\
Wilayah Kementerian Agama \\
Provinsi Lampung, 2015.
\end{tabular}

Dari tabel 1.1 di atas dapat dilihat bahwa persentase kehadiran tertinggi pada bulan oktober, yaitu sebesar $85 \%$, sedangkan terendah pada bulan februari, yaitu sebesar $70 \%$. Hal ini mencerminkan kinerja pegawai yang belum optimal terlebih lagi jika dikaitkan dengan motivasi dan komitmen organisasi yang ada. Dalam kaitannya dengan kinerja pegawai, masih terdapat kualitas hasil kerja yang belum optimal tidak sesuai yang dengan apa yang diharapkan oleh instansi. Hal tersebut tentunya harus segera dibenahi agar para pimpinan dan bawahan pada pegawai Kantor Wilayah Kementerian Agama Provinsi Lampung dapat bekerja lebih optimal.

Berdasarkan latar belakang, beberapa permasalahan yang teridentifikasi dan di duga dapat mempengaruhi kinerja pegawai antara lain:

1. Kompetensi pegawai masih rendah terlihat dari masih adanya pegawai yang bekerja tidak berdasarkan latar belakang pendidikannya dan kurangnya pengetahuan tentang pekerjaannya sehingga ia tidak menguasai pekerjaannya.

2. Komitmen organisasi yang rendah terlihat dari masih ada pegawai yang pegawai yang datang terlambat, tidak hadir tanpa keterangan dan pulang sebelum waktunya.

3. Kinerja pegawai menurun terlihat dari masih ada pegawai yang lambat dalam penyelesaian suatu pekerjaan dan bahkan cenderung menunda - nunda pekerjaan.

Tujuan dari penelitian ini adalah ingin mengetahui:

1. Pengaruh kompetensi terhadap kinerja pegawai pada Kantor Wilayah Kementerian Agama Provinsi Lampung.

2. Pengaruh komitmen organisasi terhadap kinerja pegawai pada Kantor Wilayah Kementerian Agama Provinsi Lampung.

3. Pengaruh kompetensi dan komitmen organisasi secara bersama - sama terhadap kinerja pegawai pada Kantor Wilayah Kementerian Agama Provinsi Lampung.

\section{Kerangka Pemikiran}

\section{Kompetensi}

Spencer \& Spencer dalam Palan (2007:45), adalah sebagai karakteristik dasar yang dimiliki oleh seorang individu yang berhubungan secara kausal dalam memenuhi kriteria yang diperlukan dalam menduduki suatu jabatan.

Kompetensi terdiri dari 5 tipe karakteristik, yaitu motif (kemauan konsisten sekaligus menjadi sebab dari tindakan), faktor bawaan (karakter dan respon yang konsisten), konsep diri (gambaran diri), pengetahuan (informasi dalam bidang tertentu) dan keterampilan (kemampuan untuk melaksanakan tugas). Hal ini sejalan dengan pendapat Becker and Ulrich dalam Suparno (2005: 24), bahwa competency refers to an individual's knowledge, skill, ability or personality characteristics that directly influence job performance. Artinya kompetensi mengandung aspek-aspek pengetahuan, keterampilan (keahlian) dan kemampuan ataupun karakteristik kepribadian yang mempengaruhi kinerja. 
Berbeda dengan Fogg (2004: 90), yang membagi Kompetensi kompetensi menjadi 2 (dua) kategori, yaitu; kompetensi dasar dan yang membedakan kompetensi dasar (Threshold) dan kompetensi pembeda (differentiating) menurut kriteria yang digunakan untuk memprediksi kinerja suatu pekerjaan. Kompetensi dasar (Threshold Competencies) adalah karakteristik utama, yang biasanya berupa pengetahuan atau keahlian dasar seperti kemampuan untuk membaca, sedangkan kompetensi differentiating adalah kompetensi yang membuat seseorang berbeda dari yang lain.

Pengertian kompetensi ini pada prinsipnya sama dengan pengertian kompetensi menurut Stephen Robbin (2007: 38), bahwa kompetensi adalah "kemampuan (ability) atau kapasitas seseorang untuk mengerjakan berbagai tugas dalam suatu pekerjaan, dimana kemampuan ini ditentukan oleh 2 (dua) faktor yaitu kemampuan intelektual dan kemampuan fisik.

Dari uraian pengertian di atas dapat ditarik kesimpulan bahwa kompetensi yaitu sifat dasar yang dimiliki atau bagian kepribadian yang mendalam dan melekat kepada seseorang serta perilaku yang dapat diprediksi pada berbagai keadaan dan tugas pekerjaan sebagai dorongan untuk mempunyai prestasi dan keinginan berusaha agar melaksanakan tugas dengan efektif.

\section{Karakteristik Kompetensi}

Menurut Prihadi (2004: 38-39), terdapat 5 (lima) karakteristik kompetensi dan merupakan indikator dari kompetensi pegawai, yaitu:

1. Motif (motive) adalah hal - hal yang seseorang pikir atau inginkan secara konsisten yang menimbulkan tindakan.

2. Sifat (traits) adalah karakteristik fisik dan respons-respons konsisten terhadap situasi atau informasi.
3. Konsep diri (Self - Concept) adalah sikap dan nilai-nilai yang dimiliki seseorang.

4. Pengetahuan (knowledge), adalah informasi yang dimiliki seseorang untuk bidang tertentu. Pengetahuan (knowledge) merupakan kompetensi yang kompleks

5. Keterampilan (skill) adalah kemampuan untuk melaksanakan suatu tugas tertentu baik secara fisik maupun mental.

Menurut Spencer and Spencer yang dikutip oleh Dharma (2003: 17), konsep diri (self- concept), watak/sifat (traits) dan motif kompetensi lebih tersembunyi (hidden), dalam (deeper) dan berbeda pada titik sentral keperibadian seseorang. Kompetensi pengetahuan (knowledge competencies) dan keahlian (skill competencies) cenderung lebih nyata (visible) dan relatif berbeda di permukaan sebagai salah satu karakteristik yang dimiliki manusia.

Kompetensi dapat dihubungkan dengan kinerja dalam sebuah model alir sebab akibat yang menunjukkan bahwa tujuan, perangai, konsep diri, dan kompetensi pengetahuan yang kemudian memprakirakan kinerja kompetensi mencakup niat, tindakan dan hasil akhir. Misalnya, motivasi untuk berprestasi, keinginan kuat untuk berbuat lebih baik dari pada ukuran baku yang berlaku dan untuk mencapai hasil yang maksimal, menunjukkan kemungkinan adanya perilaku kewiraswastaan, penentuan tujuan, bertanggung jawab atas hasil akhir dan pengambilan resiko yang diperhitungkan.

\section{Jenis Kompetensi}

Menurut Spencer and Spencer dalam Surya Dharma (2003: 47), kompetensi dapat dibagi dua kategori yaitu;
1. Kompetensi dasar (threshold competency; dan

2. Kompetensi pembeda 
(differentiating competency). Threshold competencies adalah karakteristik utama (biasanya pengetahuan atau keahlian dasar seperti kemampuan untuk membaca) yang harus dimiliki oleh seseorang agar dapat melaksanakan pekerjaannya, sedangkan differentiating competencies adalah faktor - factor yang membedakan individu yang berkinerja tinggi dan rendah.

Menurut Sanjaya (2005: 34), membagi kompetensi kedalam 3 bagian yakni:

1. Kompetensi pribadi, yakni kompetensi yang berhubungan dengan pengembangan kepribadian (personal competency)

2. Kompetensi professional, yakni kompetensi atau kemampuan yang berhubungan dengan penyelesaian tugas- tugas tertentu, dan

3. Kompetensi sosial, yakni kompetensi yang berhubungan dengan kepentingan sosial.

Sedangkan pada Kunandar (2007: 41), kompetensi dapat dibagi 5 (lima) bagian yakni:

1. Kompetensi intelektual, yaitu berbagai perangkat pengetahuan yang ada pada diri individu yang diperlukan untuk menunjang kinerja

2. Kompetensi fisik, yakni perangkat kemampuan fisik yang diperlukan untuk pelaksanaan tugas

3. Kompetensi pribadi, yakni perangkat perilaku yang berkaitan dengan kemampuan individu dalam mewujudkan diri, transformasi diri, identitas diri dan pemahaman diri.

4. Kompetensi sosial, yakni perangkat perilaku tertentu yang merupakan dasar dari pemahaman diri sebagai bagian yang tidak terpisahkan dari lingkungan sosial.

5. Kompetensi spiritual, yakni pemahaman, penghayatan serta pengamalan kaidah - kaidah keagamaan.

\section{Manfaat Kompetensi}

Kompetensi pegawai sangat diperlukan setiap organisasi terutama untuk meningkatkan kinerja. Menurut Prihadi (2004: 57), manfaat kompetensi adalah:

Prediktor kesuksesan kerja. Model kompetensi yang akurat akan dapat menentukan dengan tepat pengetahuan serta keterampilan apa saja yang dibutuhkan untuk berhasil dalam suatu pekerjaan. Apabila seseorang pemegang posisi mampu memiliki kompetensi yang dipersyaratkan pada posisinya maka ia dapat diprediksikan akan sukses.

1. Merekrut karyawan yang andal. Apabila telah berhasil ditentukan kompetensi - kompetensi apa saja yang diperlukan suatu posisi tertentu, maka dengan mudah dapat dijadikan kriteria dasar dalam rekrutmen karyawan baru

2. Dasar penilaian dan pengembangan karyawan.Indentifikasi kompetensi pekerjaan yang akurat juga dapat dipakai sebagai tolak ukur kemampuan seseorang. Dengan demikian, berdasarkan sistem kompetensi ini dapat diketahui apakah seseorang telah bagaimana mengembangkannya, dengan pelatihan dan pembinaan atau perlu dimutasikan kebagian lain.

\section{Komitmen Organisasi}

Robbins dan Judge, (2008: 100-101), memberikan definisi bahwa komitmen organisasi adalah suatu keadaan di mana seorang pegawai memihak organisasi tertentu serta tujuan-tujuan dan keinginannya untuk mempertahankan keanggotaan dalam organisasi tersebut demi terwujudnya situasi yang kondusif manakala pegawai dan organisasi memiliki sinergi yang sama dalam orientasi pencapaian tujuan, berusaha keras mencapai target yang ditentukan 
adalah suatu kemestian ketika seorang pegawai memihak pada organisasi.

Steers dalam jurnal Andi (2010: 89), mendefinisikan komitmen organisasi sebagai rasa identifikasi, keterlibatan dan loyalitas yang dinyatakan oleh seorang pegawai terhadap organisasinya. Rasa identifikasi berarti kepercayaan terhadap nilai - nilai organisasi. Keterlibatan berarti kesediaan untuk berusaha sebaik mungkin demi kepentingan organisasi dan loyalitas diartikan sebagai keinginan untuk tetap menjadi anggota organisasi yang bersangkutan.

\section{Faktor-Faktor Komitmen Organisasi}

Untuk melihat faktor-faktor dari komitmen organisasi, maka terlebih dahulu perlu untuk melihat dimensi dari komitmen organisasi itu sendiri. Karena dari dimensi ini, kita akan lebih jelas melihat aspek apa saja yang menjadi faktor- faktor komitmen organisasi. Adapun tiga dimensi terpisah dari komitmen organisasi akan dipaparkan pada penjelasan di bawah ini.

Dimensi komitmen organisasi menurut Robbins dan Judge (2008: 101), antara lain "Komitmen afektif, komitmen berkelanjutan dan komitmen organisasi. "Komitmen afektif dimaknai sebagai perasaan emosional untuk organisasi dan keyakinan dalam nilai - nilai organisasi tersebut, sedangkan komitmen berkelanjutan merupakan nilai ekonomi yang dirasakan ketika bertahan dengan organisasi jika dibandingkan dengan meninggalkan organisasi tersebut. Komitmen organisasi adalah komitmen untuk bertahan dengan organisasi menurut alasan-alasan moral atau etis.

Dimensi manakah yang paling dominan adalah jawaban yang tepat ketika menguraikan serangkaian pernyataan dari Robbins dan Judge (2008: 102), pada umumnya tampak bahwa komitmen afektif memiliki hubungan yang erat dengan hasil- hasil organisasional bila dibandingkan dengan dua dimensi lain. Terlihat bahwa nilai atau hasil yang lemah diperuntukkan komitmen berkelanjutan adalah masuk akal, karena komitmen ini bukan merupakan komitmen yang kuat jika dibandingkan dengan kesetiaan sebagai indikator dari komitmen afektif atau kewajiban yang menjadi indikator komitmen normatif bagi seorang pemberi kerja.

Komitmen berkelanjutan mendeskripsikan pegawai yang terikat dengan seorang pemberi kerja hanya dikarenakan tidak ada hal lain yang lebih baik.Sedangkan dalam jurnal Ryan (2009), Begley \& Cjazka, menggolongkan faktor-faktor yang mempengaruhi komitmen organisasi tersebut dalam 4 kategori, yaitu "Karakteristik individu seperti usia, tingkat pendidikan, jenis kelamin, status perkawinan; karakteristik yang berhubungan dengan pekerjaan dan karakteristik struktural." Menurut Sopiah (2008: 155), indikator untuk mengukur variabel komitmen organisasi adalah sebagai berikut:

1. Penerimaan terhadap tujuan organisasi

2. Keinginan untuk bekerja keras

3. Hasrat

\section{Kinerja Pegawai}

Yuli (2005: 89), mengemukakan bahwa "Kinerja adalah hasil kerja secara kualitas dan kuantitas yang dicapai oleh seorang pegawai dalam melaksanakan tugasnya sesuai dengan tanggung jawab yang diberikan kepadanya".

Kinerja mempunyai berbagai macam pengertian, diantaranya adalah: Malthis dan Jackson (2006: 378), mengemukakan bahwa "Kinerja pegawai pada dasarnya adalah apa yang dilakukan atau tidak dilakukan oleh pegawai." Sedangkan 
menurut Ruky (2006: 15), mengemukakan bahwa kinerja adalah catatan tentang hasil - hasil yang diperoleh dari fungsi - fungsi pekerjaan tertentu atau kegiatan tertentu selama kurun waktu tertentu.

Hasibuan (2005: 56), menyatakan kinerja adalah kesadaran dan kesediaan sesorang mentaati semua peraturan instansi dan norma - norma sosial yang berlaku. Dengan demikian, kinerja berangkat dari kesadaran diri sendiri untuk secara sukarela mentaati semua peraturan yang berlaku terkait dengan tugas pekerjaannya.

Begitu juga menurut Sulistiyani dan Rosidah (2003: 224), mengemukakan bahwa "Kinerja merupakan catatan outcome yang dihasilkan dari fungsi pegawai tertentu atau kegiatan yang dilakukan selama periode waktu tertentu. Sedangkan kinerja suatu jabatan secara keseluruhan sama dengan jumlah (rata rata) dari kinerja fungsi pegawai atau kegiatan yang dilakukan. Pengertian kinerja di sini tidak bermaksud menilai karakteristik individu tetapi mengacu pada serangkaian hasil yang di peroleh selama periode waktu tertentu".

Keith Davis dalam Mangkunegara (2004: 130), menyatakan bahwa kinerja adalah pengelolaan kegiatan guna memperkuat standar-standar organisasi. Ada dua macam kinerja, yaitu kinerja preventif dan kinerja korektif. Kinerja preventif adalah suatu upaya untuk menggerakkan pegawai mengikuti dan memenuhi pedoman kerja, aturan - aturan yang telah digariskan. Dengan cara preventif pegawai dapat memelihara dirinya terhadap peraturan- peraturan organisasi.

Dari definisi tersebut di atas maka dapat disimpulkan bahwa kinerja pegawai berkaitan dengan mempunyai rasa tanggung jawab yang tinggi dalam mencapai visi dan misi perusahaan, ketepatan dan ketaatan waktu dalam menyelesaikan setiap pekerjaan, memiliki sifat kejujuran yang tinggi dalam bekerja, kecakapan pegawai dalam melaksanakan tugas dari pimpinan, tidak menyalah gunakan wewenang yang diberikan pimpinan serta pegawai dapat melakukan proses kerja dengan baik dan sesuai dengan standar perusahaan dalam melaksanakan suatu tugas atau pekerjaan yang dibebankan kepadanya dengan mengarahkan sumber daya yang dimilikinya baik berupa kecakapan, keterampilan juga pengalaman dan kesungguhan hatinya hingga diperoleh hasil kerja yang maksimal.

Kinerja pegawai adalah tingkat kemampuan seseorang atau kelompok dalam melaksanakan tugas yang dibebankan kepadanya. Kinerja pegawai merupakan salah satu ukuran yang tegas yang dapat digunakan sebagai bahan pertimbangan dalam kenaikan pangkat dan jabatan seseorang. Kinerja pegawai juga mendorong pegawai untuk mempertinggi pengetahuan, kecakapan serta wawasannya dalam rangka mengejar prestasi kerjanya karena dengan memiliki pengetahuan, kecakapan dan wawasan yang semakin luas dan tinggi disertai prestasi kerja yang baik maka akan mendapatkan penghargaan yang layak dari organisasi.

Menurut Umar (2008: 22), kinerja pegawai adalah tingkat hasil keberhasilan seseorang secara keseluruhan selama periode tertentu di dalam melaksanakan tugas dibandingkan dengan berbagai kemungkinan, seperti standar hasil kerja, target atau sasaran atau kreteria yang telah ditentukan terlebih dahulu dan telah disepakati bersama. Aspek aspek penilaian kinerja pegawai mencakup beberapa point di antaranya:

1. Prestasi kerja, yaitu hasil kerja yang dicapai oleh seorang pegawai dalam melaksanakan tugas yang 
dibebankan kepadanya. Pada umumnya prestasi kerja dipengaruhi oleh kecakapan, keterampilan, pengalaman dan kesungguhan pegawai.

2. Tanggung jawab, yaitu kesanggupan pegawai menyelesaikan pekerjaan yang diserahkan kepadanya dengan sebaik-baiknya dan tepat waktunya serta keberanian memikul risiko atas keputusan yang diambilnya atau tindakan yang dilakukannya.

3. Ketaatan, yaitu kesanggupan pegawai untuk mentaati segala peraturan perundang - undangan dan peraturan kedinasan yang berlaku, mentaati perintah kedinasan yang diberikan oleh atasan yang berwenang, serta kesanggupan untuk tidak melanggar larangan yang ditentukan.

4. Kejujuran, yaitu ketulusan hati pegawai dalam melaksanakan tugas dan kemampuan untuk tidak menyalah gunakan wewenang yang diberikan kepadanya.

5. Kerjasama, yaitu kemampuan seseorang untuk bekerja bersamasama dengan orang lain dalam menyelesaikan sesuatu tugas yang ditentukan, sehingga mencapai daya guna dan hasil guna yang sebesar besarnya.

6. Prakarsa, yaitu kemampuan pegawai untuk mengambil keputusan, langkah $\neg$ langkah atau melaksanakan suatu tindakan yang diperlukan dalam melaksanakan tugas pokok tanpa menunggu perintah dari atasan.

Penilaian kinerja akan efektif apabila dalam penilaian kinerja benar - benar memperhatikan dan memprioritaskan dua hal berikut sebagai persyaratan :

1. Kriteria pengukuran kinerja memenuhi objektivitas.
Untuk memenuhi persyaratan ini, maka ada tiga kualifikasi penting bagi pengembangan kriteria pengukuran kinerja yang obyektif, yaitu meliputi:

Relevansi. Relevansi berarti harus ada kesesuaian antara kriteria dengan tujuan- tujuan penilaian kinerja. Misalnya apabila tujuan perusahaan adalah meningkatkan kualitas produk dan penilaian kinerja dilakukan di bagian produksi, maka kualitas pekerjaan seseorang dijadikan kriteria lebih utama dibandingkan dengan keramahan.

a).Reliabilitas, Reliabilitas berarti harus terpenuhinya konsistensi atas kriteria yang dijadikan ukuran kinerja. Dalam hal ini cara melakukan pengukuran dan pihak yang melakukan penilaian kinerja turut mempengaruhi reliabilitas pengukuran.

b).Diskriminasi, diskriminasi berarti pengukuran dan penilaian kinerja harus mampu menunjukkan perbedaanperbedaan kinerja hasil pengukuran.

Hasil pengukuran yang seragam, misalnya baik semua atau jelek semua menunjukkan tidak ditemukannya diskriminasi dalam penilaian kinerja.

2. Proses penilaian kinerja

Proses penilaian kinerja sangat penting diperhatikan. Objektivitas dalam proses penilaian berarti tidak adanya pilih kasih, pengistimewaan, atau bahkan kecurangan dalam proses penilaian kinerja terhadap pegawai tertentu.

Berdasarkan kerangka pemikiran teori di atas maka keterkaitan variabel Kompetensi dan komitmen organisasi terhadap kinerja pegawai pada Kantor Wilayah Kementerian Agama Provinsi Lampung dapat digambarkan dalam bentuk paradigma penelitian sebagai berikut : 


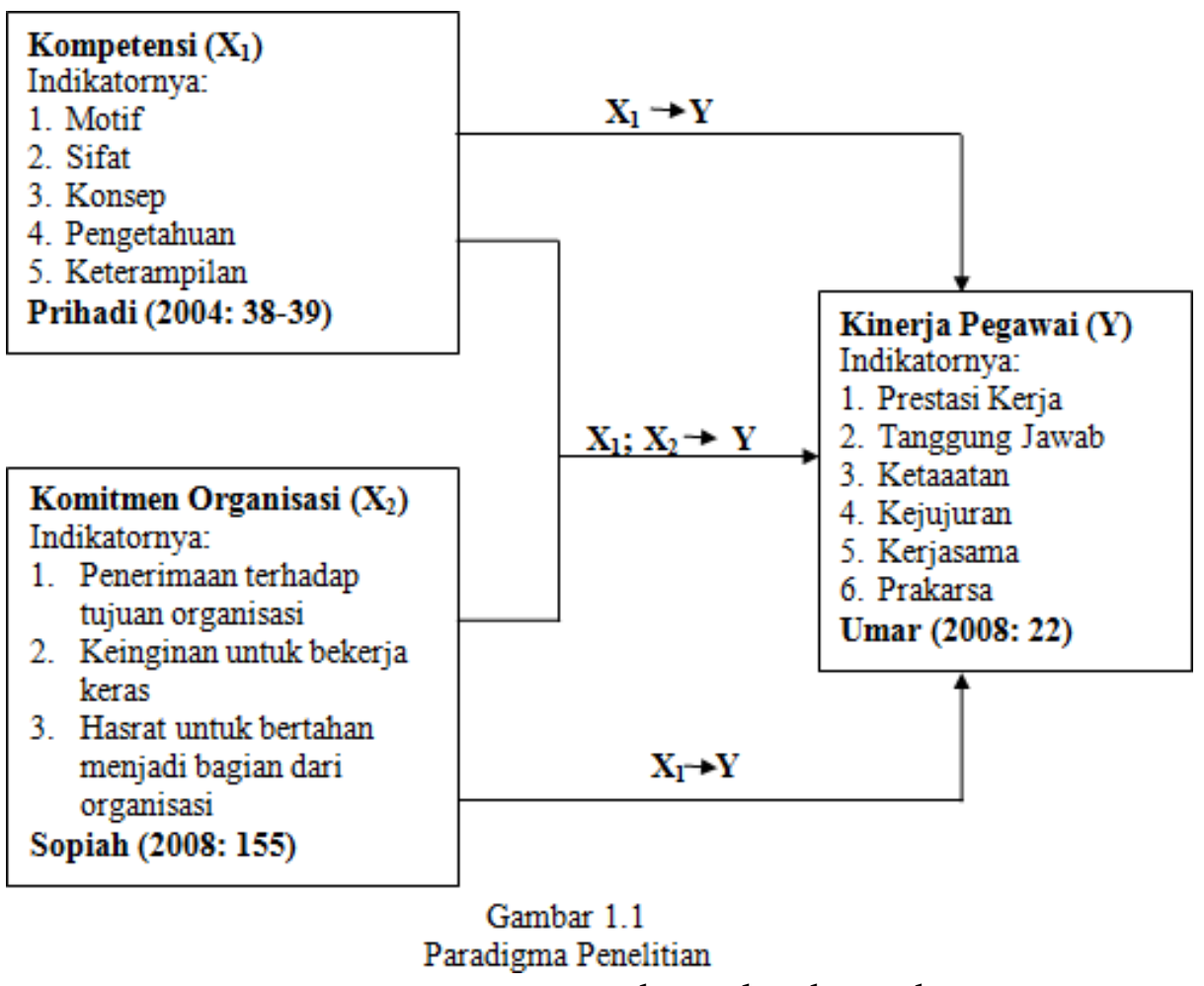

\section{Hipotesis}

Hipotesis adalah jawaban sementara yang harus dibuktikan terlebih dahulu kebenarannya. Berdasarkan latar belakang masalah dan kajian teori di atas maka peneliti mengajukan hipotesis sebagai berikut:

1. Kompetensi berpengaruh terhadap kinerja pegawai pada Kantor Wilayah Kementerian Agama Provinsi Lampung.

2. Komitmen organisasi berpengaruh terhadap kinerja pegawai pada Kantor Wilayah Kementerian Agama Provinsi Lampung.

3. Kompetensi dan komitmen organisasi secara bersama - sama berpengaruh terhadap kinerja pegawai pada Kantor Wilayah Kementerian Agama Provinsi Lampung.

\section{METODE PENELITIAN}

\section{Jenis Penelitian}

Penelitian yang dilakukan adalah penelitian deskriptif kuantitatif. Jenis penelitian ini adalah penelitian yang bermaksud membuat pemaparan secara sistimatis, faktual dan akurat mengenai fakta dan sifat populasi tertentu. Jenis penelitian yang digunakan dalam penelitian ini adalah penelitian lapangan (field reseach), bersifat kuantitatif di mana penjelasannya bersifat objektif dengan menjelaskan pendekatanpendekatan yang ada.

Penelitian ini bertujuan untuk mengetahui pengaruh kompetensi dan komitmen organisasi terhadap kinerja pegawai pada Kantor Wilayah Kementerian Agama Provinsi Lampung.

\section{Variabel Penelitian}

Variabel yang digunakan dalam penelitian ini adalah:

1. Variabel bebas (Independent Variabel) adalah variabel yang mempengaruhi variable lain, dalam penelitian ini yang menjadi variabel bebas adalah kompetensi (X1) dan komitmen organisasi (X2).

2. Variabel terikat (Dependent Variable) adalah variabel yang dipengaruhi oleh variabel lain, dalam 
penelitian ini yang menjadi variabel terikat adalah kinerja pegawai (Y).

Untuk mendapatkan dan mengumpulkan data yang sesuai dengan kebutuhan dalam penelitian ini maka teknik - teknik yang digunakan adalah sebagai berikut :

1. Observasi

Yaitu peneliti mengadakan pengamatan langsung pada objek yang akan diteliti yaitu dengan melihat data - data Sasaran Kinerja Pegawai (SKP) pada Kantor Wilayah Kementerian Agama Provinsi Lampung.

\section{Kuisioner}

Peneliti menyebar kuisioner kepada responden penelitian (pegawai pada Kantor Wilayah Kementerian Agama Provinsi Lampung) yang disusun dalam bentuk pertanyaan tertutup yang diajukan kepada responden. Teknik ini dilakukan untuk memperoleh data deskriptif yang dikuantifikasikan yang akan digunakan untuk menguji hipotesis dengan model kajian skala likert dengan 5 alternatif jawaban untuk setiap pertanyaan yang diajukan dalam daftar kuisioner.

3. Telaah Dokumentasi dan Kepustakaan

Yaitu suatu teknik pengumpulan data yang dilakukan peneliti yang diperoleh dari laporan administrasi dan kegiatan pembelajaran yang berhubungan dengan masalah yang akan diteliti yang berbentuk dokumen, seperti; absensi pegawai, dsb.

Metode Penetapan Sampel Populasi Menurut Arikunto (2002) apabila objek penelitian kurang dari 100 maka lebih baik diambil semua, selanjutnya jika jumlah lebih dari 100 maka dapat diambil antara 10\% - 15\% atau 20\% $25 \%$. Jumlah pegawai pada Kantor Wilayah Kementerian Agama Provinsi Lampung yaitu sebanyak 184 orang, maka responden yang digunakan yaitu $20 \% \times 184=36,8$ (dibulatkan menjadi 37), pimpinan dan peneliti tidak termasuk sebagai responden.

\section{HASIL DAN PEMBAHASAN}

Uji Hipotesis Parsial Kompetensi (X1) terhadap Kinerja pegawai (Y)

Uji hipotesis parsial Kompetensi (X1) terhadap kinerja pegawai (Y) pada Kantor Wilayah Kementerian Agama Provinsi Lampung menggunakan hasil hitungan melalui Program Statistik SPSS 21 sebagai berikut:

Berdasarkan hasil penelitian maka diperoleh hasil uji hipotesis parsial kompetensi terhadap kinerja pegawai sebagai berikut:

Tabel 3.7

Uji Hipotesis Parsial Kompetensi terhadap Kinerja Pegawai

Tabel 2. Uji Hipotesis Parsial Kompetensi terhadap Kinerja Pegawai

\begin{tabular}{|c|c|c|c|c|c|c|}
\hline \multicolumn{7}{|c|}{ Coefficients $^{a}$} \\
\hline \multirow[t]{2}{*}{ Model } & & \multicolumn{2}{|c|}{ Unstandardized Coefficients } & \multirow{2}{*}{$\begin{array}{c}\text { Standardized } \\
\text { Coefficients } \\
\text { Beta }\end{array}$} & \multirow[t]{2}{*}{ T } & \multirow[t]{2}{*}{ Sig. } \\
\hline & & $B$ & Std. Error & & & \\
\hline \multirow{2}{*}{1} & (Constant) & 17,291 & 8,912 & & 1,940 &, 060 \\
\hline & Kompetensi & ,697 & 157 &, 600 & 4,440 &, 000 \\
\hline
\end{tabular}

a. DependentVariable:Kinerja_Peg

Berdasarkan hasil Uji t didapat nilai

thitung 4,440. Apabila dibandingkan dengan $\mathrm{t}$ tabel pada taraf signifikan yaitu 1,687 , maka thitung $4,440>\mathrm{t}$ tabel 
1,687 sehingga dapat disimpulkan bahwa; Ha yang menyatakan terdapat pengaruh variabel kompetensi (X1) terhadap variabel kinerja pegawai (Y) pada Kantor Wilayah Kementerian Agama Provinsi Lampung. Jadi variabel kompetensi (X1) berpengaruh terhadap variabel kinerja pegawai (Y).

Persamaan regresi antara variabel kompetensi (X1) terhadap variabel kinerja pegawai (Y) adalah $\mathrm{Y}=17,291$ $+0,697 \mathrm{X} 1$, yang artinya setiap kenaikan satu point daripada variabel kompetensi akan diikuti oleh naiknya variabel kinerja pegawai pada Kantor Wilayah Kementerian Agama Provinsi Lampung sebesar 0,697 point atau 69,7\% (100\% x 0,697).

Berdasarkan hasil penelitian di atas, maka diperoleh koefisien determinasi kompetensi kerja terhadap kinerja pegawai adalah sebagai berikut:

Tabel 3. Koefisien Determinasi Kompetensi terhadap Kinerja Pegawai

\begin{tabular}{lclll}
\multicolumn{5}{c}{ Model Summary } \\
\hline Model & $\mathrm{R}$ & $\begin{array}{l}\mathrm{R} \\
\text { Square }\end{array}$ & $\begin{array}{l}\text { Adjusted } \\
\text { R Square }\end{array}$ & $\begin{array}{l}\text { Std. } \\
\text { Error of } \\
\text { the } \\
\text { estimate }\end{array}$ \\
\hline 1 & $.600^{\mathrm{a}}$ & .360 & .342 & 4.425 \\
\hline a. & Predictors: (Constant), Kompetensi &
\end{tabular}

Berdasarkan hasil perhitungan tingkat korelasi antar variabel melalui Program
Statistik SPSS 21 diperoleh besarnya tingkat korelasi antara variabel kompetensi (X1) dengan kinerja pegawai (Y) pada Kantor Wilayah Kementerian Agama Provinsi Lampung adalah sebesar 0,600 . Jika dikonsultasikan dengan tabel interpretasi koefesien korelasi (Sugiyono: 2008), maka tingkat korelasi kompetensi (X1) dengan variabel kinerja pegawai (Y) pada Kantor Wilayah Kementerian Agama Provinsi Lampung termasuk dalam kategori korelasi "kuat" yakni terletak pada $(0,600-0,799)$.

Koefisien determinasi $0,360 \times 100 \%=$ $36 \%$. Dapat disimpulkan bahwa variabel kompetensi (X1) menjelaskan variasi perubahan terhadap variabel kinerja pegawai (Y) pada Kantor Wilayah Kementerian Agama Provinsi Lampung $36 \%$, sedangkan sisanya sebesar $64 \%$ dijelaskan oleh faktor lain yang tidak dikaji dalam penelitian ini.

\section{Uji Hipotesis Parsial Komitmen Organisasi (X2) terhadap Kinerja Pegawai (Y) Berdasarkan hasil penelitian, maka diperoleh data hasil uji hipotesis secara parsial komitmen organisasi (X2) terhadap kinerja pegawai (Y) sebagai berikut:}

Tabel 3. Uji Hipotesis Parsial Komitmen Organisasi terhadap Kinerja Pegawai

\begin{tabular}{|c|c|c|c|c|c|}
\hline \multirow{3}{*}{ Model } & \multicolumn{4}{|c|}{ Coefficient $^{\mathrm{a}}$} & \multirow{3}{*}{ Sig. } \\
\hline & $\begin{array}{l}\text { Standard } \\
\text { Coeffici }\end{array}$ & & $\begin{array}{l}\text { Standardized } \\
\text { Coefficients }\end{array}$ & $\mathrm{t}$ & \\
\hline & $\mathrm{B}$ & $\begin{array}{l}\text { Std. } \\
\text { Error }\end{array}$ & Beta & & \\
\hline (Constant) & 29.703 & 7.308 & & 4.065 & .000 \\
\hline Komit-Org & .474 & .127 & .532 & 3.719 & .001 \\
\hline
\end{tabular}

Berdasarkan hasil Uji t didapat nilai $\mathrm{t}$ hitung 3,719. Apabila dibandingkan dengan $\mathrm{t}$ tabel pada taraf signifikan yaitu 1,687 , maka thitung $3,719>\mathrm{t}$ tabel 1,687, sehingga dapat disimpulkan bahwa; Hipotesis yang menyatakan terdapat pengaruh komitmen organisasi (X2) terhadap kinerja pegawai (Y) pada Kantor Wilayah Kementerian Agama Provinsi Lampung dapat diterima. Jadi variabel komitmen organisasi berpengaruh terhadap kinerja pegawai 
(Y) pada Kantor Wilayah Kementerian Agama Provinsi Lampung.

Persamaan regresi antara variabel Komitmen organisasi (X2) terhadap Kinerja pegawai $(\mathrm{Y})$ adalah $\mathrm{Y}=29,703$ $+0,474 \mathrm{X} 2$, yang artinya setiap kenaikan satu point dari variabel komitmen organisasi akan diikuti oleh variabel kinerja pegawai sebesar 0,474 point atau $47,4 \%(100 \% \times 0,474)$.

Berdasarkan hasil penelitian di atas, maka diperoleh koefisien determinasi komitmen organisasi terhadap kinerja pegawai adalah sebagai berikut:

Tabel 5. Koefisien Determinasi Komitmen Organisasi terhadap Kinerja Pegawai

\begin{tabular}{lllll}
\multicolumn{9}{c}{ Model Summary } \\
\hline Model & $\mathrm{R}$ & $\mathrm{R}$ & Adjusted \\
& Square & R Square & $\begin{array}{l}\text { Std. } \\
\text { Error of } \\
\text { the } \\
\text { estimate }\end{array}$ \\
\hline 1 & \multicolumn{1}{c}{$.532^{\text {a }}$} & .283 & .263 & 4.684 \\
\hline b. & Predictors: (Constant), Komit_Org &
\end{tabular}

Berdasarkan hasil perhitungan tingkat korelasi antar variabel melalui Program Statitik SPSS 21, diperoleh besarnya tingkat korelasi antara variabel komitmen organisasi (X2) dengan kinerja pegawai (Y) pada Kantor Wilayah Kementerian Agama Provinsi
Lampung adalah sebesar 0,532. Jika dikonsultasikan dengan tabel interpretasi koefesien korelasi maka tingkat korelasi komitmen organisasi (X2) dengan variabel kinerja pegawai (Y) pada Kantor Wilayah Kementerian Agama Provinsi Lampung termasuk dalam kategori korelasi "sedang" yakni terletak pada $(0,400-0,699)$.

Koefisien Determinasi $(\mathrm{KD})=0,283 \mathrm{x}$ $100 \%=28,3 \%$. Dapat disimpulkan bahwa variabel komitmen organisasi (X2) menjelaskan variasi perubahan variable kinerja pegawai (Y) sebesar $28,3 \%$, sedangkan sisanya sebesar $71,7 \%$ dijelaskan oleh faktor lain yang tidak dikaji dalam penelitian ini.

\section{Uji Hipotesis Simultan Kompetensi (X1) dan Komitmen Organisasi (X2) terhadap Kinerja Pegawai (Y)}

Uji Hipotesis secara simultan variabel kompetensi (X1) dan komitmen organisasi (X2) secara bersama-sama (simultan) terhadap variabel kinerja pegawai (Y) pada Kantor Wilayah Kementerian Agama Provinsi Lampung melalui hasil perhitungan melalui Program SPSS 21 sebagai berikut:

Tabel 4. Uji Hipotesis Simutan Kompetensi (X1) dan Komitmen Organisasi (X2) secara bersama-sama (simultan) terhadap Kinerja Pegawai

\begin{tabular}{llllll}
\multicolumn{8}{c}{ ANOVA $^{\mathbf{a}}$} \\
\hline Model & Sum of Squares & df & Mean Square & F & Sig. \\
\hline Regression & 419,736 & 2 & 209,868 & 10,951 & $.000^{\text {a }}$ \\
Residual & 651,562 & 34 & 19,164 & & \\
Total & 1071,297 & 36 & & & \\
\hline a. Dependent Variable : Kinerja_Peg & & & & \\
b. Predictors: (Constant), Komit_Org, Kompetensi &
\end{tabular}

Dari uji anova atau $\mathrm{F}$ test didapat $\mathrm{F}$ hitung sebesar 10,951 dan jauh lebih besar dari nilai $\mathrm{F}$ tabel 4,105 , pada taraf signifikan 5\%. Jadi $\mathrm{F}$ hitung adalah lebih besar dari Ftabel ( $\mathrm{F}$ hitung $>\mathrm{F}$ tabel), maka kompetensi (X1) dan komitmen organisasi (X2) secara bersama-sama (simultan) berpengaruh terhadap kinerja pegawai (Y) pada Kantor Wilayah Kementerian Agama Provinsi Lampung. Dengan demikian maka hipotesis yang diajukan yang menyatakan terdapat pengaruh kompetensi (X1) dan komitmen organisasi (X2) secara bersama-sama terhadap kinerja pegawai (Y) pada 
Kantor Wilayah Kementerian Agama Provinsi Lampung adalah dapat terbukti atau diterima berdasarkan hasil analisis yang dilakukan di atas.

Tabel 5. Koefisien Determinasi secara Simultan

\begin{tabular}{lllll}
\multicolumn{6}{c}{ Model Summary } \\
\hline Model & $\mathrm{R}$ & $\mathrm{R}$ & $\begin{array}{l}\text { Adjusted } \\
\text { R Square }\end{array}$ & $\begin{array}{l}\text { Std. } \\
\text { Error of } \\
\text { the } \\
\text { estimate }\end{array}$ \\
\hline 1 & $.626^{\mathrm{a}}$ & .392 & .356 & 4.378 \\
\hline c. & Predictors: (Constant), Komit_Org, Kompetensi
\end{tabular}

Korelasi kompetensi dan komitmen organisasi dengan kinerja pegawai sebesar 0,636 , artinya ketiga variabel tersebut mempunyai hubungan yang erat dan positif. Koefisien Determinasi $(\mathrm{KD})=0,392 \times 100 \%=39,2 \%$. Jadi dapat ditarik kesimpulan bahwa besarnya pengaruh kompetensi dan komitmen organisasi terhadap kinerja pegawai sebesar $39,2 \%$ dan sisanya sebesar $60,8 \%$ akibat penyesuaian faktor lain yang tidak penulis teliti dalam penelitian ini.

\section{Analisis Regresi Linier Berganda Kompetensi (X1) dan Komitmen Organisasi (X2) terhadap Kinerja Pegawai (Y)}

Berdasarkan hasil penelitian, maka diperoleh data perhitungan regresi linier berganda kompetensi (X1) dan komitmen organisasi (X2) terhadap kinerja pegawai (Y) sebagai berikut:

\begin{tabular}{|c|c|c|c|c|c|}
\hline \multicolumn{6}{|c|}{ Coefficients ${ }^{\mathrm{a}}$} \\
\hline \multirow[t]{2}{*}{ Model } & \multicolumn{2}{|c|}{$\begin{array}{l}\text { Standardized } \\
\text { Coefficients }\end{array}$} & $\begin{array}{l}\text { Standardized } \\
\text { Coefficients }\end{array}$ & $\mathrm{t}$ & Sig. \\
\hline & B & $\begin{array}{l}\text { Std. } \\
\text { Error }\end{array}$ & Beta & & \\
\hline (Constant) & 15.6 & 8.906 & & 1.754 & .000 \\
\hline Kompetensi & 24 & .208 & .442 & 2.463 & .000 \\
\hline Komit-Org & $\begin{array}{l}.513 \\
.212\end{array}$ & .160 & .238 & 1.326 & .000 \\
\hline
\end{tabular}

Berdasarkan tabel di atas, kemudian dimasukkan persamaan :

$\mathrm{Y}=15,624+0,513 \mathrm{X}_{1}+0,212 \mathrm{X}_{2}$.

1. Setiap terjadi peningkatan nilai pada variabel kompetensi sebesar satu point, maka Kinerja pegawai akan meningkat sebesar 0,513 point atau $51,3 \%$.

2. Setiap terjadi peningkatan nilai pada variabel komitmen organisasi sebesar satu point, maka kinerja pegawai akan meningkat sebesar 0,212 point atau $21,2 \%$.

Berdasarkan keterangan di atas dapat ditarik kesimpulan bahwa nilai koefisien regresi $\mathrm{X}_{1}=0,513$ lebih besar daripada koefisien regresi $X_{2}=0,212$. Hal ini menunjukkan bahwa pengaruh variabel kompetensi lebih tinggi atau dominan dibandingkan komitmen organisasi dalam meningkatkan kinerja pegawai pada Kantor Wilayah Kementerian Agama Provinsi Lampung.

\section{Pembahasan}

Dari hasil penelitian dinyatakan bahwa Kompetensi pada Kantor Wilayah Kementerian Agama Provinsi Lampung dalam kategori baik. Hasil perhitungan tingkat korelasi antara Variabel Kompetensi (X1) dengan Kinerja pegawai (Y) sebesar 0,600 termasuk dalam kategori kuat yakni $(0,600-$ 0,799). Uji hipotesis parsial melalui uji $\mathrm{t}$ diperoleh nilai thitung Kompetensi terhadap Kinerja pegawai sebesar 4,440 dan thitung 4,440 > t tabel 1,687. Persamaan regresi antara Kompetensi dan Kinerja pegawai pada Kantor 
Wilayah Kementerian Agama Provinsi Lampung adalah sebesar $\mathrm{Y}=17,291+$ $0,697 X 1$, yang menunjukkan setiap kenaikan satu point dari variabel kompetensi akan diikuti oleh naiknya variabel kinerja pegawai pada Kantor Wilayah Kementerian Agama Provinsi Lampung sebesar 0,697 point atau $69,7 \%$. Besarnya koefisien determinasi kompetensi terhadap kinerja pegawai adalah $36 \%$. Hal ini menunjukkan bahwa kompetensi juga memberikan pengaruh dalam meningkatkan kinerja pegawai sebesar $69,7 \%$ sedangkan sisanya sebesar $30,7 \%$ dipengaruhi oleh faktor lain yang tidak diteliti pada penelitian ini.

Hasil penelitian menunjukkan bahwa komitmen organisasi (X2) pegawai pada Kantor Wilayah Kementerian Agama Provinsi Lampung dalam kategori baik. Hasil perhitungan tingkat korelasi antara variabel komitmen organisasi (X2) dan variabel kinerja pegawai (Y) pada Kantor Wilayah Kementerian Agama Provinsi Lampung adalah sebesar 0,532, termasuk dalam kategori sedang yakni $(0,400-0,699)$. Uji hipotesis parsial melalui uji $t$ diperoleh nilai $t$ hitung komitmen organisasi terhadap kinerja pegawai sebesar 3,719 dan thitung 3,719> ttabel 1,687. Persamaan regresi komitmen organisasi dengan kinerja pegawai pada Kantor Wilayah Kementerian Agama Provinsi Lampung adalah $\mathrm{Y}=29,703+$ $0,474 X 2$, yang menunjukkan setiap kenaikan satu point dari variabel komitmen organisasi akan diikuti oleh naiknya variabel kinerja pegawai pada Kantor Wilayah Kementerian Agama Provinsi Lampung sebesar 0,474 point atau 47,4\%. Besarnya Koefisien Determinasi komitmen organisasi (X2) terhadap kinerja pegawai (Y) adalah $28,3 \%$. Hal ini menunjukkan bahwa komitmen organisasi juga memberikan pengaruh dalam meningkatkan kinerja pegawai sebesar $47,4 \% \%$ sedangkan sisanya sebesar 52,6\% dipengaruhi oleh faktor lain yang tidak dikaji dalam penelitian ini.

Hasil pengujian hipotesis secara simultan kompetensi dan komitmen organisasi terhadap kinerja pegawai dibuktikan dari hasil perhitungan uji $\mathrm{F}$ memperoleh hasil 10,951 dan jauh lebih besar dari nilai $\mathrm{F}$ tabel 4,105 , pada taraf signifikan 5\%. Jadi $\mathrm{F}$ hitung adalah lebih besar dari Ftabel ( $\mathrm{F}$ hitung $>\mathrm{F}$ tabel). Persamaan regresi linier berganda antara kompetensi dan komitmen organisasi terhadap kinerja pegawai adalah

$\mathrm{Y}=15,624+0,513 \mathrm{X}_{1}+0,212 \mathrm{X}_{2}$ yang artinya Setiap terjadi peningkatan nilai pada variabel kompetensi sebesar satu point, maka Kinerja pegawai akan meningkat sebesar 0,513 point atau $51,3 \%$ dan Setiap terjadi peningkatan nilai pada variabel komitmen organisasi sebesar satu point, maka kinerja pegawai akan meningkat sebesar 0,212 point atau 21,2\%. Besarnya koefisien determinasi kompetensi $\left(\mathrm{X}_{1}\right)$ dan komitmen organisasi $\left(\mathrm{X}_{2}\right)$ secara bersama-sama terhadap kinerja pegawai (Y) adalah 39,2\%. Berdasarkan keterangan di atas dapat ditarik kesimpulan bahwa nilai koefisien regresi $\mathrm{X} 1=0,513$ atau $51,3 \%$ lebih besar daripada koefisien regresi X2 = 0,212 atau 21,2\%. Hal ini menunjukkan bahwa pengaruh variabel kompetensi lebih tinggi atau dominan dibandingkan komitmen organisasi dalam meningkatkan kinerja pegawai pada Kantor Wilayah Kementerian Agama Provinsi Lampung. Hal ini menunjukkan bahwa terdapat pengaruh variabel kompetensi dan komitmen organisasi terhadap kinerja pegawai pada Kantor Wilayah Kementerian Agama Provinsi Lampung sebesar $72,5 \%$ sedangkan sisanya sebesar $27,5 \%$ dipengaruhi oleh faktor lain yang tidak dikaji dalam penelitian ini. 


\section{KESIMPULAN DAN IMPLIKASI}

\section{Kesimpulan}

Berdasarkan analisis data dan pembahasan pada bab sebelumnya, diperoleh kesimpulan sebagai berikut:

Terdapat pengaruh kompetensi terhadap kinerja pegawai pada Kantor Wilayah Kementerian Agama Provinsi Lampung, hal ini terbukti dari hasil uji hipotesis parsial melalui uji t diperoleh nilai thitung kompetensi terhadap kinerja pegawai sebesar 4,440 dan $t$ hitung 4,440 > t tabel 1,687. Persamaan regresi antara kompetensi dan kinerja pegawai pada Kantor Wilayah Kementerian Agama Provinsi Lampung adalah sebesar $\mathrm{Y}=17,291+0,697 \mathrm{X} 1$, yang menunjukkan setiap kenaikan satu point dari variabel kompetensi akan diikuti oleh naiknya variabel kinerja pegawai pada Kantor Wilayah Kementerian Agama Provinsi Lampung sebesar 0,697 point atau $69.7 \%$. Hal ini menunjukkan bahwa kompetensi juga memberikan pengaruh dalam meningkatkan kinerja pegawai sebesar $69,7 \%$ sedangkan sisanya sebesar $30,3 \%$ dipengaruhi oleh faktor lain yang tidak dikaji dalam penelitian ini.

1. Terdapat pengaruh variabel komitmen organisasi terhadap kinerja pegawai pada Kantor Wilayah Kementerian Agama Provinsi Lampung, hal ini terbukti dari hasil perhitungan Uji hipotesis parsial melalui uji t diperoleh nilai thitung komitmen organisasi terhadap kinerja pegawai sebesar 3,719 dan thitung 3,719> ttabel 1,687. Persamaan regresi komitmen organisasi dengan kinerja pegawai pada Kantor Wilayah Kementerian Agama Provinsi Lampung adalah Y $=29,703+0,474 \mathrm{X} 2$, yang menunjukkan setiap kenaikan satu point dari variabel komitmen organisasi akan diikuti oleh naiknya variabel kinerja pegawai pada Kantor
Wilayah Kementerian Agama Provinsi Lampung sebesar 0,474 point atau $47,4 \%$. Hal ini menunjukkan bahwa komitmen organisasi juga memberikan pengaruh dalam meningkatkan kinerja pegawai sebesar $47,4 \% \%$ sedangkan sisanya sebesar $52,6 \%$ dipengaruhi oleh faktor lain yang tidak dikaji dalam penelitian ini.

2. Hasil pengujian hipotesis secara simultan kompetensi dan komitmen organisasi terhadap kinerja pegawai dibuktikan dari hasil perhitungan uji $\mathrm{F}$ yang memperoleh hasil 10,951 dan jauh lebih besar dari nilai $F$ tabel 4,105, pada taraf signifikan 5\%. Jadi F hitung adalah lebih besar dari $\mathrm{F}$ tabel ( $\mathrm{F}$ hitung $>\mathrm{F}$ tabel). Persamaan regresi linier berganda antara kompetensi dan komitmen organisasi terhadap kinerja pegawai adalah $\mathrm{Y}=15,624+0,513 \mathrm{X} 1+$ $0,212 \mathrm{X} 2$, yang artinya Setiap terjadi peningkatan nilai pada variabel kompetensi sebesar satu point, maka Kinerja pegawai akan meningkat sebesar 0,513 point atau $51,3 \%$ dan Setiap terjadi peningkatan nilai pada variabel komitmen organisasi sebesar satu point, maka kinerja pegawai akan meningkat sebesar 0,212 point atau $21,2 \%$. Hal ini menunjukkan bahwa terdapat pengaruh variabel kompetensi dan komitmen organisasi terhadap kinerja pegawai pada Kantor Wilayah Kementerian Agama Provinsi Lampung sebesar $72,5 \%$ sedangkan sisanya sebesar $27,5 \%$ dipengaruhi oleh faktor lain yang tidak dikaji dalam penelitian ini.

\section{Implikasi}

Berdasarkan hasil penelitian di atas, implikasi kedepan dirumuskan sebagai berikut :

1.Variabel Kompetensi, yang perlu mendapat perhatian untuk peningkatan kompetensi indikator mengenai pegawai memiliki pengetahuan yang relevan dengan bidang pekerjaannya karena nilai indikator tersebut yang 
paling rendah. Peningkatan indikator ini dapat dilakukan oleh pimpinan dengan cara membagi tugas dan pekerjaan pegawai sesuai dengan pengetahuan dan keterampilan yang dimilikinya, sehingga pegawai dapat bekerja dengan lebih efektif dan efisien.

2. Variabel komitmen organisasi yang perlu mendapat perhatian indikator mengenai pegawai saling berkoordinasi dalam menyelesaikan tugas dan pekerjaan karena indikator ini mendapatkan nilai yang paling rendah. Peningkatan indikator ini dapat dilakukan dengan pimpinan memberikan bimbingan dan arahan pentingnya bekerja tim dalam suatau penyelesaian pekerjaan.

3. Variabel kinerja pegawai yang perlu mendapat perhatian adalah item pernyataan indikator mengenai pegawai menyelesaikan pekerjaan tepat pada waktunya yang telah ditentukan kantor karena indikator ini mendapatkan nilai yang paling rendah. Peningkatan indikator ini dapat dilakukan oleh pimpinan dengan memberikan tugas dan pekerjaan sesuai dengan job description masingmasing pegawai sehingga pekerjaan dapat dengan mudah diselesaikan dan tepat waktu.

\section{DAFTAR PUSTAKA}

Achmad S. Ruky. 2006. Sistem Manajemen Kinerja. Jakarta : PT Bumi Aksara. Aditya, kesuma. 2007. Optimalisasi Media Pembelajaran. Jakarta : PT. Grasindo. Anoraga. 2006. Psikologi Kerja. Rhneka Cipta Jakarta.

Anwar Prabu Mangkunegara. 2002. Manajemen Sumber Daya Manusia. PT. Remaja Rosda Karya,
Bandung.

Arief, Edy Irawan. 2014. Pedoman Penulisan Tesis Pascasarjana Saburai. Bandar Lampung.

Arikunto, S (2002) Prosedur Penelitian. Jakarta: Rineka Cipta.

Carrillo, P., Robinson. 2004. Knowledge management in UK construction. Strategies. Dharma, Surya. 2003. Manajemen Supervisi, Petunjuk Praktis Bagi Para. Supervisor. Jakarta: Raja Grafindo Persada.

Gibson, J.L. 2003. Struktur Organisasi dan Manajemen. Jakarta: PT Bumi Aksara. Gouzali, Saydam. 2006. Manajemen Sumber Daya Manusia. PT. Gunung Agung.

H. Malayu, S.P. Hasibuan. 2007. Manajemen Sumber Daya

Manusia. Jakarta : Cetakan

9. PT. Bumi Aksara.

Handoko, T. Hani, 2003, Manajemen Sumber Daya Manusia, Edisi Kedua, Cetakan. Keempat belas, BPFE, Yogyakarta.

Hasibuan, Malayu, S.P. 2003. Manajemen Dasar, Pengertian dan Masalah. Jakarta : PT Toko Gunung Agung.

Hasibuan, Malayu SP. 2005. Manajemen Sumber Daya Manusia. Edisi Revisi. Jakarta: PT. Bumi Aksara.

Keith Davis dalam Mangkunegara. (2004). Prestasi Kerja Dalam Organisasi. Grafindo. Jakarta.

Keputusan Kepala Badan Kepegawaian Negeri Nomor: 46A Tahun 2003. Tentang Pengertian Kompetensi.

Kunandar, 2007. Guru Profesional: Implementasi Kurikulum Tingkat Satuan. Bandung: Alfabeta.

Marihot T. E Hariandja. 2005. Manajemen Sumber Daya Manusia. PT. Gramedia Widiasarana Indonesia, Jakarta.

Mathis. L. Robert dan Jackson. H. John. 2006. Manajemen Sumber Daya Manusia. Jakarta : PT. Bumi 
Aksara.

Milton Fogg, 2004. The Greatest Networker in the Workd, the Three Rivers. Press,. New York.

Munandar. 2008. Psikologi Industri dan Organisasi. UI Press: Jakarta. Nitisemito, 2006. Manajemen Pemasaran, Ghalia Indonesia: Jakarta.

Pabundu. 2006. Budaya Organisasi dan Peningkatan Kinerja Perusahaan. Jakarta: PT. Bumi Aksara.

Palan, R. 2007. Competency Management. Jakarta: Penerbit PPM.

Peraturan Pemerintah (PP) No. 23 Tahun 2004. Tentang Badan Nasional Sertifikasi Profesi (BNSP).

Prihadi, S. 2004. Kinerja, Aspek Pengukuran. Jakarta : PT. Gramedia.

Rivai. 2001. Manajemen Sumber Daya Manusia. Edisi Revisi. Jakarta: PT Bumi Aksara. Roe. Robert A. 2001. Trust Implications for Performance and Efectiveness. European Journal.

Sedarmayanti. 2001. Sumber Daya Manusia dan Produktivitas Kerja. Bandung: Mandar Maju.

Sedarmayanti. 2011. Manajemen Sumber Daya Manusia, Reformasi Birokrasi dan Manajemen Pegawai Negeri Sipil. (cetakan kelima). Bandung: Mandar Maju.

Siagian. 2004. Manajemen Sumber Daya Manusia. Penerbit PT. Bumi Aksara, Jakarta. Simamora. 2004. Manajemen Sumber Daya Manusia. Edisi Ke-3. STIE YKPN. Sugiyono. 2004. Statistik Untuk Penelitian. Cetakan 4. Bandung : Alfabeta.

Sulistiyani dan Rosidah. 2003. Manajemen Sumber Daya Manusia. Cetakan. Pertama. Penerbit : Graha Ilmu. Yogyakarta. Suparno. 2005. Pengaruh Kompetensi, Motivasi Kerja dan Kecerdasan.
Bandung: Penerbit Alfabeta.

Timpe. 2000. Memimpin Manusia, Seri Ilmu dan Seni Manajemen Bisnis. PT. Gramedia Asri Media.

Umar, Husein. 2008. Riset Pemasaran dan Perilaku Konsumen. Jakarta : PT. Gramedia dan Jakarta Business Research Center.

Uyanto, S, Stanislaus. 2006. Pedoman Analisis Data dengan SPSS. Edisi Pertama. Cetakan Pertama. Yogyakarta : Graha Ilmu.

Wibowo. 2007. Manajemen Kinerja. PT. Raja Grafindo Parsada: Jakarta.

Wina Sanjaya. 2005. Pembelajaran dalam Implementasi Kurikulum Berbasis. Jakarta: Kencana.

Yulia, Sari, 2005. Riset Manajemen Sumber Daya Manusia dalam organisasi. Gramedia Pustaka Utama. Jakarta.

Yuli, 2005. Manajemen Sumber Daya Manusia. UMM Press. Malang. 